\title{
Pedagojik Formasyon Eğitimi Alan Öğretmen Adaylarının Mesleklerine, Geleceklerine, İstihdamlarına ve Eğitim Politikalarına İlişkin Metaforik Algıları
}

\author{
Doç.Dr.Şenay Sezgin Nartgün \\ Abant Izzet Baysal Üniversitesi-Türkiye \\ szbn@yahoo.com
}

\author{
İlknur Gökçer (Yük.Lis.Öğr.) \\ Milli Ĕ̆itim Bakanliğı-Türkiye \\ mrs.chaucer@hotmail.com
}

\begin{abstract}
Özet
$\mathrm{Bu}$ araştırmanın temel amacı, öğretmen adayı olan formasyon öğrencilerinin gelecek, istihdam, KPSS, politika ve eğitim politikasına ilişkin algılarını metaforlar aracılığıyla ortaya çıkartmaktır. Araştırmanın çalışma grubunu, Abant İzzet Baysal Üniversitesi Eğitim Fakültesi bünyesinde 2013-2014 Eğitim öğretim yılı bahar yarıyılında formasyon eğitimi almakta olan toplam 50 öğrenci oluşturmaktadır. Araştırmanın uygulaması, ders öğretmeninden izin alınarak araştırmacı ve ders öğretmeni tarafından gerçekleştirilmiştir. Öncelikle öğrencilere metafor tekniği hakkında bilgi verilmiştir. Daha sonra öğrencilerden cümleleri tamamlamaları istenmiştir. Öğrencilerde verilen kelimeleri kullanarak ve sadece tek bir metafor üzerinde yoğunlaşarak düşüncelerini dile getirmeleri istenmiştir. Öğrencilere yöneltilen cümle ile ilgili metaforlar oluşturmaları için bir ders saati zaman verilmiştir. Araştırma 50 formasyon öğrencisi ile gerçekleştirilmiş, ancak bunlardan anlamlı metafor kurabilen, ya da kurduğu metaforun sebebini mantıklı şekilde açıklayabilen 45 formasyon öğrencisinin çalışması değerlendirilmiştir. Katılımcıların geliştirdikleri metaforların analiz edilmesi ve yorumlanması süreci; (1) metaforların belirlenmesi (2) metaforların sınıflandırılması (3) kategori geliștirme olmak üzere üç aşamada gerçekleşmiştir. Araştırmanın bulgularına göre katılımcllar 190 adet geçerli metafor üretmişlerdir. Bu metaforlar ortak özellikleri bakımından 17 farklı kavramsal kategori altında toplanmıştır. Araştırmanın bulgularına göre; formasyon öğrencilerinin derin bir gelecek kaygısı yaşadıkları görülmektedir. formasyon öğrencilerinin gelecek kavramı umutsuzluk ve belirsizlik ile özdeşleşmiştir. Oluşturulan 30 metafordan 20 tanesi çelişki, bilinmezlik denklemi, belirsizlik, illüzyon, sisli yol ve karmaşa metaforlarından oluşmaktadır. Buna karşın bir kısım formasyon öğrencisinin gelecekten ümitli oldukları ve geleceği umut metaforuyla açıladıkları görülmüştür. Katılımcıların KPSS'ye dair algılarının oldukça olumsuz olduğu bulunmuştur. Formasyon öğrencilerinin çoğu Kamu Personeli Seçme Sınavi'nı eziyet, zulüm, kaos, kabus, ölüm, engel, basamak, gereksiz, hayal metaforlarıyla açıklamışlardır. Katılımcıların, politika kavramına tereddütle yaklaştığı ağırlıklı olarak dürüst olmayan, kaygan bir zemin olarak algıladıkları anlaşılmıştır.
\end{abstract}

Anahtar Kelimeler: Öğretmen Adayı, Metafor Tekniği, Eğitim, Politika

\section{GİRIŞ̧}

Metaforlar yaşadığımız dünyayı kavramamızda, kendimizi toplum içerisinde ifade etmemizde ve başkalarıyla diyalog kurmamızda sık sık başvurduğumuz, ancak kullanırken de pek farkına varmadığımız ifadelerdir. Metafor olgusu “. . . bireylerin kendi dünyalarını anlamalarına ve yapılandırmalarına yönelik güçlü bir zihinsel haritalama ve modelleme mekanizması olarak" (Arslan ve Bayrakçı, 2006) 
günümüzde eğitimcilerin dikkatini fazlasıyla çekmektedir. Metafor kelimesi, Yunanca "Metapherein" kelimesinden türemiştir. Meta, değiştirmek demektir ve pherein ise taşımak anlamındadır (Levine, 2005). Metafor bir fikri, obje ya da eylemi bir sözcük veya deyim ile herhangi duruma benzeterek ifade etme biçimidir (Palmer ve Lundberg, 1995'ten akt., Tamimi, 2005) Aristotales'e (2004) göre ise "bir şeyi başka bir şeye ait olan bir adla çağırmaktır". Bu bağlamda metaforlar, dile zenginlik ve çeşitlilik katmaktadır (Wulf ve Dudis, 2005).

Metaforlar, insanların belli bir olguyu başka bir olguyla görmesini sağlayan zihinsel modellerdir (Saban, 2008). Gillis ve Johnson'un (2002) ile Lakoff ve Johnson (2005) belirttiği gibi, metaforlar, olmak istediğimiz veya olamadığımız, olageldiğimiz, olmaktan kaçındığımız ve dahi olabileceğimiz benlik algısını anlamamıza yardımcı olurlar. Bu ve bunun gibi sebeplerden dolayı anlaşılması güç konularda metaforların kullanılması uygun olabilir. Metaforlar canl1- cansız, soyutsomut olabileceği gibi olumlu ve olumsuzda olabilirler. Metaforlar ilgi toplama ve sorgulama aracı da olabilmektedirler. Metaforlar anlaşılamayan konuların daha kolay anlaşılmasını sağladığı gibi problemlerin net bir şekilde ortaya konulmasında önemli rol oynamakta, en önemlisi de düşüncelerin özetlenmesini sağlamaktadır (Saban, 2006; Yob, 2003; akt. Şirin, vd., 2012). Ayrıca bu yönüyle metaforlar, öğretmen yetiştirme programlarında sunulan farklı formasyon derslerinde farklı teorilerle ilişki kurmak için birer pedagojik araç olarak kullanılabilir (Carlson, 2001; Goldstein, 2005; Marshall, 1990; akt., Saban ve vd., 2006).

Ancak, bundan fazlası olduğu, dünyayı görme ve anlama biçimi olduğu da literatürde vurgulanmaktadır (Morgan, 1980). Dilsel benzetme olan metaforda üç unsur (benzeyen, benzeyen ve benzetilen) göze çarpar. Bunları Saban (2004) bir örnekle şöyle açıklamaktadır: 'Öğretmen pusula gibidir' denildiğinde pusulanın özellikleri öğretmene yüklenir. Böylece, bir metafor kullanılmış olur. Bu üç unsur, benzeyen (öğretmen), benzetilen (pusula) ve benzetilene ait özelliktir (yön bulduruculuk). Bunun yanında bir metaforda, kelimenin gerçek anlamından farklı kullanılması, benzetme amaçlanması ve kelimenin asıl manasında kullanılmasını ortaya çıkaran bir halin bulunması da gerekmektedir (Yıldırım ve Şimşek, 2005).

Son zamanlarda metaforla ilgili eğitim araştırmaları sıkça yapılmaktadır. Bunun nedeni olarak sosyal bilimlerde metaforların önemli etkilerinin olması gösterilebilir (Bredeson, 1988). Bu alanda yapılan çalışmalar; öğrenci, öğretmen, müdür ve okul gibi kavramlar hakkında metaforlar, bilgi kavramına ilişkin metaforlar, öğretme kavramı ile ilgili dört metaforun üniversite düzeyinde incelenmesi gibi çalışmalardır (Inbar,1996; Bozlk,2002; Saban, 2004, 2008; McEwan, 2007). Açıkça görüleceği üzere, öğretmen ve öğrencilerin öğrenme, öğretme, bilgi, okul gibi kavramlara ilişkin metaforlarını konu edinen ulusal ve uluslararası literatürde birçok çalışma bulunmasına karşın, gelecek, istihdam, KPSS, politika ve eğitim politkasına ilişkin kavramlarla ilgili araştırmaya rastlanamamıştır. Bu kavramlar üniversite mezunlarını yakından ilgilendiren konulardır. Üniversite sınavından alınan puanlar ve rehber öğretmenlerin yönlendirmesi ile öğrenciler üniversitelerde bölüm tercihleri yapmaktadırlar (Aksu, Engin Demir, Daloğlu, Yıldırım and Kiraz, 2010). En az dört y1llık bir süreçten sonra üniversiteden mezun olan bir bireyin en önemli gayesi iş sahibi 
olabilmek ve geleceğini garantiye almaktır. Visakorpi, Stankovic, Pedrosa ve Rozsnyai (2008) yaptıkları araştırmada Türkiye' de yükseköğretim mezunlarının yüksek işsizlik oranlarına sahip olduklarını belirtmektedir. Bu bağlamda mezunlar hem çalışma hem de kamu da hizmet sektöründe çalışma isteği içindedirler. Kamuda çalışabilmek için her bir adayın Kamu Personeli Seçme Sınavına (KPSS) girmesi gerekmektedir. Adaylar bu sınavdan alınan puan ve mezun olunan alan doğrultusunda açık olan kadrolara atama yapilabilmektedir. Giderek bir "sınav toplumu" haline gelen ülkemizde öğretim kademelerine girişten, istihdama değin birçok kademede sınavlar kullanılmakta ve seçimler yapılmaktadır. Bu sınavlarda başarılı olanlar, alanın gereklerine sahip kabul edilmekte, başarısız olanlar ise bu yetilerden yoksun kabul edilmektedir. Sınırlı bir zaman aralığında ve bilişsel taban ağırlıklı olarak yapılan çoktan seçmeli anlayış pratik düşünüşe belirli bir hıza sahip olanları avantajlı hale getirmektedir. Test tekniğine sahip olan bireyler üniversite sınavında ve sonrası yapılan iş sınavlarında başarılı olmaktadırlar. Böylece bireylerin yaratıcılıkları, becerileri vb. özellikleri geri planda kalmaktadır (Sezgin ve Duran, 2011).

Kamu Personel Seçme Sınavına getirilen eleştirilerin ardından eklenen alan bilgisi derslerinin öğretmen adaylarının kaygı düzeylerine olumlu ya da olumsuz bir etkisi olmamıştır. Katılımcıların çoğunluğu KPSS sınavının çevreyle iletişimlerini, sosyal ilişkilerini ve sanatsal, kültürel ve sportif faaliyetlere katılımlarını olumsuz etkilediğini belirtmektedirler. Karaca' nın (2011) araştırmasında öğretmen adaylarının KPSS hakkında olumsuz bir tutuma sahip oldukları ve bu sinava yönelik alternatif önerileri destekledikleri yönünde bulgu görülmektedir.

$\mathrm{Bu}$ bağlamda bu araştırmanın temel amac1, öğretmen adayı olan formasyon öğrencilerinin gelecek, istihdam, meslek, KPSS, politika ve eğitim politikasına ilişkin algılarını metaforlar aracılığıyla ortaya çıkartmaktır. Bu amaç çerçevesinde, aşağıdaki sorulara cevap aranmıştır:

\section{YÖNTEM}

$\mathrm{Bu}$ araştırmada, formasyon öğrencilerinin söz konusu altı kavrama yönelik metaforik düşünme durumlarını belirlemek için nitel araştırma desenlerinden "olgu bilim" kullanılmıştır. "Olgu bilim (fenomenoloji) deseni, farkında olduğumuz ama derinlemesine ve ayrıntılı bir anlayışa sahip olmadığımız olgulara odaklanmaktadır. Olgu bilim, bize tümüyle yabancı olmayan aynı zamanda da tam anlamını kavrayamadığımız olguları araştırmayı amaçlayan çalışmalar için uygun bir araştırma zemini oluşturur" (Yıldırım ve Şimşek, 2006).

\section{Çalışma Grubu}

Araştırmanın örneklemini 2013-2014 eğitim- öğretim yılının bahar yarıyılında Dünya Üniversitesi Eğitim Fakültesi bünyesinde formasyon eğitimi alan 50 öğrenci oluşturmaktadır. Araştırmaya katılan öğrencilerin $38^{\prime}$ i k1z ve 12 'si de erkek öğrencilerden oluşmaktadır. 


\section{Verilerin Toplanması}

Araştırmanın uygulaması, ders öğretmeninden izin alınarak araştırmacı ve ders öğretmeni tarafından gerçekleştirilmiştir. Öncelikle öğrencilere metafor tekniği hakkında bilgi verilmiştir. Daha sonra öğrencilerden cümleleri tamamlamaları istenmiştir. Ögrrencilerde verilen kelimeleri kullanarak ve sadece tek bir metafor üzerinde yoğunlaşarak düşüncelerini dile getirmeleri istenmiştir. Öğrencilere yöneltilen cümle ile ilgili metaforlar oluşturmaları için bir ders saati zaman verilmiştir. Öğrencilerin oluşturdukları bu metaforlar araştırmanın temel veri kaynağını oluşturmaktadır.

\section{Verilerin Analiz Edilmesi ve Yorumlanması}

Araştırmanın uygulama aşaması 50 formasyon öğrencisi üzerinde gerçekleştirilmiş, ancak bunlardan anlamlı metafor kurabilen, ya da kurduğu metaforun sebebini mantıklı şekilde açıklayabilen 45 formasyon öğrencisinin çalışması değerlendirilmiştir. Çalışmada görüşmelerin yazılı olarak kayıtlarının alınması, araştırma ekibi tarafından doğru ve kapsamlı bilgi alınması, araştırma raporlaştırılırken katılımcılardan alıntıların yapılması ve alıntıların ekleme yapılmadan olduğu gibi verilmesi araştırmanın geçerliliğini artırıcı önlemler olarak (Yıldırım ve Şimşek; 2006) kullanılmıştır. Araştırmanın güvenilirliği ile ilgili olarak ise elde edilen metaforların belirlenen kavramsal kategorileri temsil edip etmemesi açısından iki uzman görüşüne başvurulmuş, uzmanların ve araştırmacıların değerlendirmeleri görüş birliği ve görüş ayrılığı sayıları belirlenmiştir (Miles \& Huberman, 1994). Buradan \%95 düzeyinde bir uzlaşma (güvenirlik) sağlandığı görülmektedir.

Çalışma analiz edilirken aşağıdaki adımlar izlenmiştir.

1. Adlandırma aşaması: İlk olarak katılımcılar tarafından üretilen metaforların geçici bir listesi yapılmış, daha sonra ise öğrencilerin anlamlı metaforlar ve cümleler kurup kurmadıkları kontrol edilmiştir. Bu aşamada sınıflama yapmak amaciyla her katılımcının kurduğu metafor kodlanmıştır. Herhangi bir metaforun kullanılmadığı, alakasız bağlantıların kurulduğu, nedeni açıklanamayan metaforların bulunduğu kağıtlar daha sonra elenmek üzere işaretlenmiştir.

2. Tasnif etme aşaması: $\mathrm{Bu}$ aşamada "metafor analizi" teknikleri kullanılarak her metafor, parçalara ayrıştırılmış ve diğer metaforlarla benzerlikleri veya ortak özellikleri bakımından veriler teker teker gözden geçirilerek analiz edilmiştir. Bu amaç için katılımcıların yazdıkları her metafor (1) metaforun konusu, (2) metaforun kaynağ1, (3) metaforun konusu ile kaynağı arasındaki ilişki bakımından analiz edilmiştir. 48 katılımcıdan toplam 190 geçerli metafor elde edilmiştir. Bu aşamada, bu metaforlar tekrar alfabetik sıraya göre dizilmiş ve ham veriler ikinci kez gözden geçirilerek metaforların her biri için, onu en iyi temsil ettiği düşünülen örnek metafor ifadelerinin derlenmesiyle birlikte örnek metafor listesi oluşturulmuştur. Bu liste iki temel amaca yönelik olarak oluşturulmuştur. Bunlar; (a) Metaforların belli bir kategori altında toplanmasında bir başvuru kaynağı olarak kullanmak 
ve (b) bu araştırmanın veri analizi sürecini ve yorumlarını geçerli k1lmaktır.

3. Kategori geliştirme aşaması: öğretmen adayı olan formasyon öğrencileri tarafından üretilen metaforlar, sözkonusu kavramlara ilişkin sahip oldukları ortak özellikler bakımından incelenmiştir. Bu aşamada özellikle katılımcılar tarafından oluşturulan 190 metafor dikkate alınarak her metaforun formasyon öğrencisi tarafından nasıl kavramsallaştırdığına bakılmıştır. $\mathrm{Bu}$ amaç için toplam 17 farklı kavramsal kategori oluşturulmuştur.

\section{BULGULAR VE YORUM}

\section{1. "Gelecek" kavramına yönelik metaforlar:}

Katılımcıların oluşturdukları metaforlar dört kategoride toplanmıştır. Oluşturulan metaforlara ilişkin neden cümlelerinden alıntılar da yapılmıştır.

\section{Kategori 1: Belirsizlik Temas1}

Bu kategoride 9 tane metafor oluşmuştur. Formasyon öğrencilerine göre gelecek belirsizdir; bilinmezdir.

- 'Gelecek bilinmez gibidir çünkü hiçbir zaman karşımıza neler çıkacağını bilemeyiz. Biz planlar yaparken başımıza gelenlerdir.'

- 'Gelecek belirsiz gibidir çünkü uçsuz bucaksızdır.'

Kategori 2: Umut Temas1

$\mathrm{Bu}$ kategoride 9 tane metafor kullanılmıştır. Öğretmen adaylarına göre gelecek umuttur; ümit vaat eder.

- 'Gelecek umut gibidir çünkü umut var oldukça gelecek şekillenir.'

- ' Gelecek umut gibidir çünkü ümit olmadan bir gelecek düşünülemez.'

Kategori 3: Yansıma Temas1

Bu kategoride 2 tane metafor kullanılmıştır. Öğretmen adaylarına göre gelecek aynaprojeksiyon gibidir.

- 'Gelecek ayna gibidir çünkü bugün yaptıklarımızı emeklerimizi gelecekte yaşarız.'

Kategori 4: Gök Cisimleri Teması

Bu kategoride 7 metafor oluşmuştur. Öğretmen adayları 'gelecek' kavramını çeşitli gök cisimlerine ve coğrafi olgulara benzetmişlerdir.

- 'Gelecek gökyüzü gibidir çünkü aydınlıktır ve el değmemiştir.'

- ' Gelecek güneş gibidir çünkü hayallerimi her zaman sıcak tutar.' 


\section{2. "KPSS" kavramına yönelik metaforlar:}

Oluşturulan metaforlara ilişkin neden cümlelerinden alıntılar da yapılmıştır. Formasyon öğrencilerinin oluşturdukları metaforlar üç kategoride toplanmıştır.

Kategori 1: Yarışma Teması

$\mathrm{Bu}$ kategoride 10 tane metafor oluşmuştur. Formasyon öğrencilerine göre KPSS yarışma gibidir.

- 'KPSS yarış gibidir çünkü geleceğimizi kurtarmanın bir yolu olarak görülüyor.'

- 'KPSS yarış gibidir çünkü uzun bir hazırlık süreci vardır.'

Kategori 2: Ölçek Teması

Bu kategoride 4 metafor kullanılmıştır. Öğretmen adaylarına göre KPSS bir ölçek ya da süzgeç gibidir.

- ' KPSS ölçek gibidir çünkü bilgilerimizi ölçer.'

- ' KPSS elek gibidi çünkü KPSS elek olarak kullanılarak işe yarayanlar seçilir.'

Kategori 3: Negatif Unsurlar

Bu kategoride 7 metafor oluşmuştur. Öğretmen adayları KPSS kavramını eziyete, zulme, kâbusa hatta ölüme benzetmişlerdir.

- 'KPSS kâbus gibidir çünkü uyanmak istersin.'

- 'KPSS işkence gibidir çünkü hayatını her şeyini sınırlıyor seni bir adaya mahkûm ediyor. Aylarca emek sarf edip sınav denen gereksiz şeyle her şey bitiyor.'

- ' KPSS ölüm gibidir çünkü KPSS'nin gerçekten ne kadar zorlu bir süreç olduğunu biliyorum.'

\section{3. "İstihdam" kavramına yönelik metaforlar}

Bu alandaki metaforlar ilaç teması altında verilmiştir.

Kategori 1: İlaç Teması

$\mathrm{Bu}$ kategoride üç metafor kullanılmıştır.

- Öğretmen adaylarına göre istihdam ilaç gibidir; iyileştirendir.

- 'İstihdam kemoterapi gibidir çünkü hayata tutunursunuz.'

-'İstihdam ilaç gibidir çünkü hasta ilaca ne kadar muhtaçsa işsizler de istihdama o kadar muhtaçtır.'

\section{4. "Meslek" kavramına yönelik metaforlar:}

Oluşturulan metaforlara ilişkin cümlelerden alıntılar da yapılmıştır. Katılımcı öğretmen adaylarının oluşturdukları metaforlar değerli taş-maden ile hayat olgusu şeklinde iki kategoride toplanmıştır. 
Kategori 1: Değerli Taş- Maden Teması

Bu kategoride 2 metafor oluşmuştur. Öğretmen adayları meslek kavramını altına ve madene benzetmişlerdir.

- 'Meslek altın bilezik gibidir çünkü büyüklerimiz öyle der.'

- ' Meslek altın gibidir çünkü ayarı ne kadar iyi ise o kadar çok kazandırır.'

Kategori 2: Hayat Olgusu

$\mathrm{Bu}$ kategoride 6 metafor oluşmuştur. Öğretmen adayları meslek kavramını hayatın kendisi olarak görmektedir.

- 'Meslek hayat gibidir çünkü hayatın zorlukları olduğu gibi iniş çıkışları da vardır. Meslekte de süreklilik ve bunun devamı çok önemlidir.'

- 'Meslek hayat gibidir çünkü kişi mesleği ile yaşamını sürdürür.'

\section{5. "Politika" kavramına yönelik metaforlar:}

Oluşturulan metaforlara ilişkin cümlelerden alıntılar da yapılmıştır. Formasyon öğrencilerinin oluşturdukları metaforlar üç kategoride toplanmıştır.

\section{Kategori 1: Oyun Temas1}

Bu kategoride 4 metafor kullanılmıştır. Öğretmen adayları politika kavramını çeşitli oyunlara benzetmişlerdir.

- ' Politika körebe gibidir çünkü kimin kimi gammazladığı belli değildir.'

- 'Politika söz oyunu gibidir çünkü politikacılar ne kadar güzel ve etkili konuşurlarsa o kadar iyi politikacı olurlar.'

Kategori 2: Yalan Olgusu

Bu kategoride 5 metafor oluşmuştur. Öğretmen adayları politika kavramını yalan ile özdeşleştirmişlerdir.

- 'Politika yalan söylemek gibidir çünkü herkesin doğrusu farklıdır.'

- 'Politika yalan gibidir çünkü kulağa hoş gelse de olmayacağını biliriz.'

Kategori 3: Belirsizlik- Değişkenlik Olgusu

$\mathrm{Bu}$ kategoride 6 metafor oluşturmuştur. Öğretmen adayları politikayı belirsiz ve sürekli değişen kavramlara benzetmişlerdir.

- 'Politika bukalemun gibidir çünkü ortama göre renk değiştirir.'

- 'Politika Rize'nin havası gibidir çünkü ne zaman ağlayacağı ne zaman güleceği belli değildir.'

6. “Türkiye'de eğitim politikası" kavramına yönelik metaforlar:

Oluşturulan metaforlara ilişkin cümlelerden alıntılar da yapılmıştır. Formasyon öğrencilerinin oluşturdukları metaforlar oyuncak temasında bir kategoride toplanmıştır. 
Kategori 1: Oyuncak Temas1

$\mathrm{Bu}$ kategoride 12 metafor oluşmuştur. Formasyon öğrencileri Türkiye'deki eğitim politikasını daha çok yapboza, labirente ve başka türlü oyun ve oyuncaklara benzetmişlerdir.

- 'Türkiye'de eğitim politikası yapboz gibidir çünkü her zaman ve her an değişebilmektedir.'

- 'Türkiye' de eğitim politikası oyuncak gibidir çünkü sürekli değişim geçirir.'

\section{SONUÇ, TARTIŞMA ve ÖNERİLER}

$\mathrm{Bu}$ araştırma formasyon öğrencilerinin, öğrencilik yılları süresince gerçekleştirdikleri gözlemlerine ve farklı yapıdaki öğretmenlerle diyalogları sonucunda edindikleri tecrübelere bağlı olarak gelecek, KPSS, istihdam, meslek, politika ve Türk Eğitim Politikası kavramlarına yönelik sahip oldukları algıları metaforlar aracılığıyla ortaya çıkarmak amacıyla hazırlanmıştır. Bu araştırmanın bulgularında birkaç önemli nokta dikkat çekmektedir.

Öncelikle formasyon öğrencilerinin derin bir gelecek kaygısı yaşadıkları görülmektedir. Bu durum farklı alanlardan mezun olmalarına rağmen mezun oldukları alanla ilgili bir alanda istihdam edilmek amacıyla çaba göstermek yerine öğretmenlik formasyonu almaları ile de örtüşmektedir. Çünkü ekonomik gücünü kazanamayan genç ailesine bağımlı yaşamaya devam etmek zorunda kalmakta, bağımsız bir yaşam kuramamaktadır. Bu da gelecek hakkında karamsarlığa kapılmasına neden olmaktadır (Kıcır, 2010). Bu çalışmada da formasyon öğrencilerinin gelecek kavramı umutsuzluk ve belirsizlik ile özdeşleşmiştir. Oluşturulan 30 metafordan 20 tanesi çelişki, bilinmezlik denklemi, belirsizlik, illüzyon, sisli yol ve karmaşa metaforlarından oluşmaktadır. Buna karşın bir kısım formasyon öğrencisinin gelecekten ümitli oldukları ve geleceği umut metaforuyla açıkladıkları görülmüştür. Diğer yandan Mütevellioğlu, Zanbak ve Mert (2010) çalışmalarında gençlerin geleceğe karşı kötümser bir bakış açısında ve çoğunluğu iş bulabilecekleri konusunda karamsar olduklarını bulmuşlardır. Dursun ve Aytaç (2009) da çalışmalarında öğrencilerin kaygı ve umutsuzluklarını etkileyen faktörlerden en önemlisinin gelecek ve iş bulma endişesi olduğunu vurgulamaktadırlar.

İkinci olarak katılımcıların KPSS'ye dair algılarının oldukça olumsuz olduğu görülmüştür. Formasyon öğrencilerinin çoğu Kamu Personeli Seçme Sınavı'nı eziyet, zulüm, kaos, kabus, ölüm, engel, basamak, gereksiz, hayal metaforlarıyla açıklamışlardır. Buna karşın istihdam ve meslek kavramları öğretmen adayları tarafından ilaç, altın bilezik, maden, ihtiyaç ve gereklilik olarak görülmektedir. KPSS'yi iş bulma ile aynı kefeye koyan adaylar geleceğe kaygı ile bakmaktadırlar (Atav ve Sönmez, 2013). KPSS denilince öğretmen adaylarının akıllarına daha çok "yorgunluk, sıkıntı ve memurlar.net, vb." kelimelerinin gelmesi dikkat çeken önemli bir husustur. Öğretmen adayları KPSS'ye hazırlanmak amacıyla çok yoğun bir çalışma temposuna girmeleriyle beraber atanamama kaygısı ve sıkıntısı onları oldukça yıpratmakta (Sezgin ve Duran, 2011) hatta KPSS sebebi ile son sınıfta derslerine bile gereken önemi verilememektedir (Eraslan, 2009). Daha önce yapılan çalışmalarda öğretmen 
adaylarını Kamu Personel Seçme Sınavında alan bilgisine yer verilmemesini yoğun biçimde eleştirdikleri görülmektedir. Oysa ki bu çalışma son yıllarda KPSS'ye dahil edilen özel alan bilgisi testlerinin pedagojik formasyon alan ögrrencilerin kayg1 düzeylerini düşürmediğini, sınava karşı yoğun bir olumsuz tutum geliştirmiş olduklarını göstermektedir.

Üçüncü olarak katılımcıların, politika kavramına tereddütle yaklaştığ1 ağırlıklı olarak dürüst olmayan, kaygan bir zemin olarak algıladıkları anlaşılmıştır. Formasyon öğrencileri politikaya dair yalan, söz oyunu, bukalemun, çıngırakl yılan, hastalık, hava durumu gibi metaforlar kullanmışlardır. Türkiye' de eğitim politikasının ise tamamen değişken bir yapıda olduğunu güven vermediğini bu durumun umutsuzluk ve mutsuzluk yarattığını ifade etmişlerdir. Katılımcılar Türk eğitim politikası ile ilgili oyun, yapboz, labirent, bukalemun, sömürgeci politika, rüzgar gülü, siyaset, çürük bina, yamalı bohça metaforlarını kullanmışlardır. Yılmaz ve Altınkurt'un ( 2011) çalışmasında da "eğitim yapıp yıkılan bir bina olarak tanımlanmış... Bunun bir milleti yok ettiği" sonucuna ulaşılmıştır. Örücü (2014) ise eğitim sistemin politik yönünü yansıtan metaforları "hamur, aşure ve reklam pazarlama" olarak belirtmektedir. Sonuç olarak da farklı iktidarların sisteme yön vermelerini yansıttığı ifade etmiştir.

Sonuç olarak, bu araştırmanın bulguları, katılımcıların gelecek, KPSS, istihdam, meslek, politika ve Türk eğitim politikası kavramlarına ilişkin sahip oldukları kişisel algıları ortaya çıkarmada sahip oldukları zihinsel imgeleri anlamada, açı̆̆a çıkarmada ve açıklamada güçlü birer araştırma aracı olarak kullanılabilir. Bu çalışmada da mezun olmalarının üzerinden belli bir zaman geçmesine rağmen hala uzman oldukları alanda istihdam edilemeyen, her gün değişen eğitim ve istihdam politikaları ile gelecek kaygıları daha da artan, bu ve bunun gibi sebeplerle pedagojik formasyon alan, uzmanlığı olmasa da öğretmen olmak isteyen, geleceğini güvence altına almak isteyen bir grupla çalışılmıştır. Çıkan sonuçlar yaşadıkları süreci oldukça iyi özetlemektedir. Bu doğrultuda aşağıdaki öneriler sunulabilir.

- Ülke istihdam ve eğitim politikaları yeniden gözden geçirilip uzun vadeli planlarla desteklenmelidir.

- Yeni neslin hayata karşı bu kadar olumsuz olan bakış açısını değiştirecek istihdam alanları oluşturulmalıdır.

- Öğretmen adayı seçiminde yaratıcılık, problem çözme, eleştirel düşünme ve iletişim becerilerini de ölçen bir araç geliştirilmelidir.

- Öğretmen adaylarının olumlu özelliklerini geliştirecek, olumsuz özelliklerini olumluya çevirecek fırsatlar sunulmalıdır.

\section{Kaynakça}

Aksu, M., Engin-Demir, C.,Daloglu, A., Yıldırım, S., ve Kiraz, E. (2010). Who are future teachers in Turkey? Characteristics of entering student teachers. International Journal of Educational Development, 30 (1), 91-101.

Aristotales (2004). Retorik (Çev. Mehmet H. Doğan). İstanbul: Yapı Kredi Yayınları. 
Arslan, M. M. ve Bayrakçı, M. (2006). Metaforik düşünme ve öğrenme yaklaşımının eğitim-öğretim açısından incelenmesi. Milli Ĕ̆itim, 35(171), 100-108.

Atay, E. ve Sönmez, S. (2013). Öğretmen adaylarının kamu personeli seçme sınavı (KPSS)'na ilişkin görüşleri. Hacettepe Üniversitesi Ĕ̆itim Fakültesi Dergisi, Özel Sayı (1), 01-13.

Aydın, F. ve Ünaldı, Ü. E. (2010). Coğrafya öğretmen adaylarının 'coğrafya' kavramına ilişkin algılarının metaforlar yardımıyla analizi. International Online Journal of Educational Sciences, 2(2), 600-622. [Internet-10.11.2014] http://www.iojes.net/userfiles/article/iojes_217.pdf

Botha, E. (2009). Why metaphor matters in education. South African of Education, 29, 431-444.

Cerit, Y. (2008). Öğretmen kavramı ile ilgili metaforlara ilişkin öğrenci, öğretmen ve yöneticilerin görüşleri. Türk Eğitim Bilimleri Dergisi, 6(4), 693-712.

Çapan, E. B. (2010). Öğretmen adaylarının üstün yetenekli öğrencilere ilişkin metaforik algıları. Uluslararası Sosyal Araştırmalar Dergisi, 3(12), 140-154.

Döş, İ. (2010). Aday öğretmenlerin müfettişlik kavramına ilişkin metafor algıları. Gaziantep Üniversitesi Sosyal Bilimler Dergisi, 9(3), 607-629.

Dursun, S. ve Aytaç, S. (2009). Üniversite öğrencileri arasında işsizlik kaygısı. Uludağ Üniversitesi İktisadi ve İdari Bilimler Fakültesi Dergisi, 28(1), 71-84.

Eraslan, A. (2009). İlköğretim Matematik Öğretmen Adaylarının ‘Öğretmenlik Uygulaması' Üzerine Görüşleri. Necatibey Eğitim Fakültesi Elektronik Fen ve Matematik Ĕ̆itimi Dergisi (EFMED). 3(1), 207-221.

Erbay, M. (2000). Plastik Sanatlar Eğitiminin Gelişimi. İstanbul: Boğaziçi, Üniversitesi Yayınları.

Forceville, C. (2002). The identification of target and source in pictorial metaphors. Journal of Pragmatics, 34, 1-14.

Gillis, C. ve Johnson, C. L. (2002). Metaphor as renewal: Re-imaginingour professional selves. English Journal, 91(6), 37-43.

Guerrero, M. C. M. \& Villamil, O. S. (2002). Metaphorical conceptualizations of ELS teaching and learning. Language Teaching Research, 6(2), 95-120.

Kaya, H. (2011). The analysis of secondary education students' perceptions towards 'The World' concept. World Applied Sciences Journal, 12(2), 190-196.

Kıcır, B. (2010). Üniversite son sınıf öğrencilerinde işsizlik kaygısı: psikolojik etmenler açısından bir inceleme. Ankara Üniversitesi Sosyal Bilimler Enstitüsü Çalışma Ekononmisi ve Endüstri İlişkileri anabilim Dalı, Yayımlanmamış Yüksek Lisans tezi, Ankara.

Levine, P.M. (2005), Metaphors and images of classrooms, Kapa Delta Pi Record, 41(4), 172-175.

Mütevellioğlu, N., Zanbak, M. ve Mert, M. (2010). İşsizlik, üniversiteli gençlik ve gelecek: bir alan araştırmasının bulguları. C.Ü. İktisadi ve İdari Bilimler Dergisi, 11(1), 207-229.

Miles, M. B.\&Huberman, M. (1994). Qualitative data analysis: An expanded sourcebook (2nd ed.). Thousand Oaks, CA: Sage.

Örücü, D. (2014). Öğretmen adaylarının okul, okul yönetimi ve Türk eğitim sistemine yönelik metaforik algıları. Kuram ve Uygulamada Eğitim Yönetimi [Educational Administration: Theory and Practice], 20(3), 327-358. doi: 10.14527/kuey.2014.014

Öztürk, Ç. (2007). Sosyal Bilgiler, Sınıf ve Fen Bilgisi Öğretmen Adaylarının 'Coğrafya' Kavramına Yönelik Metafor Durumları. Kırşehir Ë̆itim Fakültesi Dergisi, 8(2), 55-69.

Saban, A. (2008). İlköğretim I. Kademe Öğretmen ve Öğrencilerinin Bilgi Kavramına İlişkin Sahip Oldukları Zihinsel İmgeler. İlköğretim Online, 7(2), 421-455. 
Saban, A. (2009). Öğretmen Adaylarının Öğrenci Kavramına İlişkin Sahip Oldukları Zihinsel İmgeler. Türk Eğitim Bilimleri Dergisi, 7(2), 281-326

Sezgin, F. ve Duran, E. (2011). Kamu Personeli Seçme Sınavı' nın (KPSS) Öğretmen Adaylarının Akademik ve Sosyal Yaşantılarına Yansımaları. TSA Dergisi, 15(3), 9-22.

Visakorpi, J., Stankovic, F., Pedrosa, J. ve Rozsnyai, C. (2008). Türkiye' de yükseköğretim: eğilimler, sorunlar ve fırsatlar yükseköğretim sistemi üzerine 17 Türk üniversitesinin EUA-IEP kurumsal değerlendirme raporlarına dayanan gözlemler ve öneriler. Yayın No. TÜSİAD-T/2008-10/473). İstanbul.

Yılmaz, K. ve Altınkurt, Y. (2011). Öğretmen adaylarının Türk eğitim sisteminin sorunlarına ilişkin görüşleri. Uluslararası İnsan Bilimleri Dergisi, 8(1), 942-973, [Internet-10.11.2014] http://www.jhumansciences.com/ojs/index.php/IJHS/article/ viewFile/1503/692.

Yıldırım, A. ve Şimşek, H. (2006). Sosyal bilimlerde nitel araştırma yöntemleri. (6.Baskı Güncelleştirilmiş Geliştirilmiş 5. Baskı). Ankara: Seçkin Yayıncılık. 


\section{Metaphorical Perceptions of Pedagogical Formation Students on their Occupation, Future, Employment and Education Policies}

\author{
Doç.Dr.Şenay Sezgin Nartgün \\ Abant Izzet Baysal University-Turkey \\ szbn@yahoo.com
}

\author{
İlknur Gökçer (M.A.Stud.) \\ Ministiry of National Education-Turkey \\ mrs.chaucer@hotmail.com
}

\section{Extended Abstract}

Purpose: The main purpose of this research is to uncover the perceptions of the teacher candidates who are pedagogical formation students about future, employment, KPSS, politics and educational policy by means of metaphors. In accordance with this target these questions are tried to be answered: What metaphors do the teacher training students have about 'future', 'KPSS', 'employment', 'occupation', 'politics' and 'Turkish Educational Policy'?

Method: In this research to identify the metaphorical thinking states of the teacher candidates who are pedagogical formation students about those six concepts; phenomenology, one of the qualitative research designs, has been used. The sample of the study consists of the 50 students who take pedagogical formation at Abant İzzet Baysal University in the Spring Semester of the 2013-2014 Educational Year. 38 female students and 12 male students form the study group. The application of the research has been done by the lecturer and the researcher with the permission of the lecturer. In the beginning students are informed about the metaphor technique and then they are asked to complete the sentences. The students are asked to express their opinions by using the words given before and focusing on only one metaphor each time. The students are given one course time to form metaphors about the sentences given them. The metaphors created by the students form the basic data source of this study. The application phase of the study has been done on the 50 pedagogical formation students but 45 of them could set meaningful metaphors or explain the reasons of the metaphors sensibly and these 45 studies are evaluated. The research is analyzed in three phases. First of all a temporal list of metaphors produced by the participants was prepared and then the answers were checked to see whether they were meaningful or not. At this stage to make the classification each of the metaphors has been coded. Each metaphor has been splinted into pieces and compared with other metaphors in terms of similarity and common features and then the whole data has been analyzed. To reach this goal every metaphor written by the participants has been analyzed with regard to metaphor topic (1), the resource of the metaphor (2), the relationship between the topic and the resource of the metaphor (3). Totally 190 valid metaphors have been gotten from the 48 participants. In this stage these metaphors have been listed alphabetically again and the raw data has been reviewed for the second time and a sample metaphor list has been prepared. This list has been created for two basic targets. These targets are: (a) To use 
it as a reference source while collecting the metaphors under a definite category and (b) To make valid the analysis and the interpretation phases of this study. The metaphors produced by the pedagogical formation students examined in terms of common features about the concepts mentioned before. At this stage, conceptualizing of the each metaphor by the teacher training students has been searched especially considering the 190 metaphors formed by the participants. 17 different conceptual categories have been created for this goal.

Findings: Firstly, it is seen that the pedagogical formation students have deep future anxiety. This fact is parallel with the choice of taking teacher training courses instead of trying to be employed in sectors related with their branches though they were all graduated from different departments. The 20 of the 30 metaphors about this case are paradox, obscurity equation, uncertainity, illusion, foggy road and chaos. On the other hand, it is seen that some of the participants are hopeful about the future and they use hope as a metaphor for the future.

Secondly, the metaphors have clearly showed that the perceptions of the participants about the KPSS examination are too negative. Most of the students explain KPSS with torture, cruelty, chaos, nightmare, death, obstacle, step, unnecessary and dream (impossible) metaphors. In contrast with this view they see employment and the occupation concepts as medicine, golden bracelet, mine, need and necessity.

Thirdly, it is understood that participants approach the concept of politics with hesitation and mostly they perceive it as lie, dishonesty, and slippery floor. They use metaphors such as lie, figurative speech, chameleon, rattlesnake, disease, weather condition to express their ideas on politics. They point out that the Turkish Education Policy has entirely changeable structure, it is not trustful and this situation creates hopelessness and unhappiness. They use game, puzzle, labyrinth, chameleon, colonist policy, wind rose, politics, corrupt building, ragtag metaphors related with the Turkish Education Policy.

As a result, the findings of this study can be used as a powerful research device to reveal the individual perceptions of the participants about future, KPSS, employment, occupation, politics and the Turkish Education Policy, to understand, uncover and describe the cognitive images they have. This study has been carried out on the teacher training students who are unemployed although they graduated a few years ago. This study group has increasing anxiety about their future because of the changing education and employment policy yet they still take teacher training courses and they try to guarantee their future by trying to be a teacher though they do not have expertise.

Keywords: Teacher candidate, metaphors technique, education, politics. 